\title{
Re-interpreting Memory of History by Fragmented Continuum Concept in Museum Design
}

\author{
Nisita Hapsari and Nur Endah Nuffida \\ Department of Architecture, Faculty of Architecture Design and Planning, \\ Institut Teknologi Sepuluh Nopember (ITS) \\ e-mail: nuffida@arch.its.ac.id
}

\begin{abstract}
Architecture has always been considered as a carrier of messages. Stories and buildings have been tied up together since the beginning of the conscious formation of space and the first attempts to understand the world around us. Architecture that has been ruined or abandoned is also has the same condition. The 'death' could be a new beginning for buildings. An example that still exists in the present is Kedung Cowek Fort. Kedung Cowek Fort is a witness of history that still exists. The design problem which will be proposed in this final project is how the ruins of architecture could be 'revived'. Architect also responsible to how the space could be an instrument which people could experience the memory of history from the event of the past with universal language which people in the present could understand. By using historicism approach, what already happened in the past become a background for the design and by using meaning in architecture approach, those past events are interpreted to story. The tool to transfer the story into architectural design is narrative method. The building type proposed in this final project is historical museum. By giving the interpretation of historical background, people could try to understand the history from the perspective and story architect creates. In this case, history is defined as a fragmented continuum story.
\end{abstract}

Keywords—Experience, Fragment, History, Museum, Narrative.

\section{INTRODUCTION}

$\mathrm{A}$ 11 awareness of the past is founded in memory, remembering the past being crucial for the sense of identity [1]. Historical building as space of the past also have their own memory through image, progress, and time that have been passed.

Indonesia as a wealthy country of heritage and culture, has many historical buildings that need to be properly capitalized on. One of the nation's heritage is fortification. The existence of the forts is spread to regions all around Indonesia, including in Surabaya. There were 11 forts had ever been built around Surabaya [2].

But now, their greatness time had been passed. They are abandoned and not well maintained. One of those forts, Kedung Cowek Fort, even got called as "The Last Standing Fort" in the book Benteng Benteng Soerabaia [3]. It is because compared to another forts which was built around Surabaya, Kedung Cowek Fort still has its entire construction and the because the structure tends to look solid. But, not many people knows about this historical building.
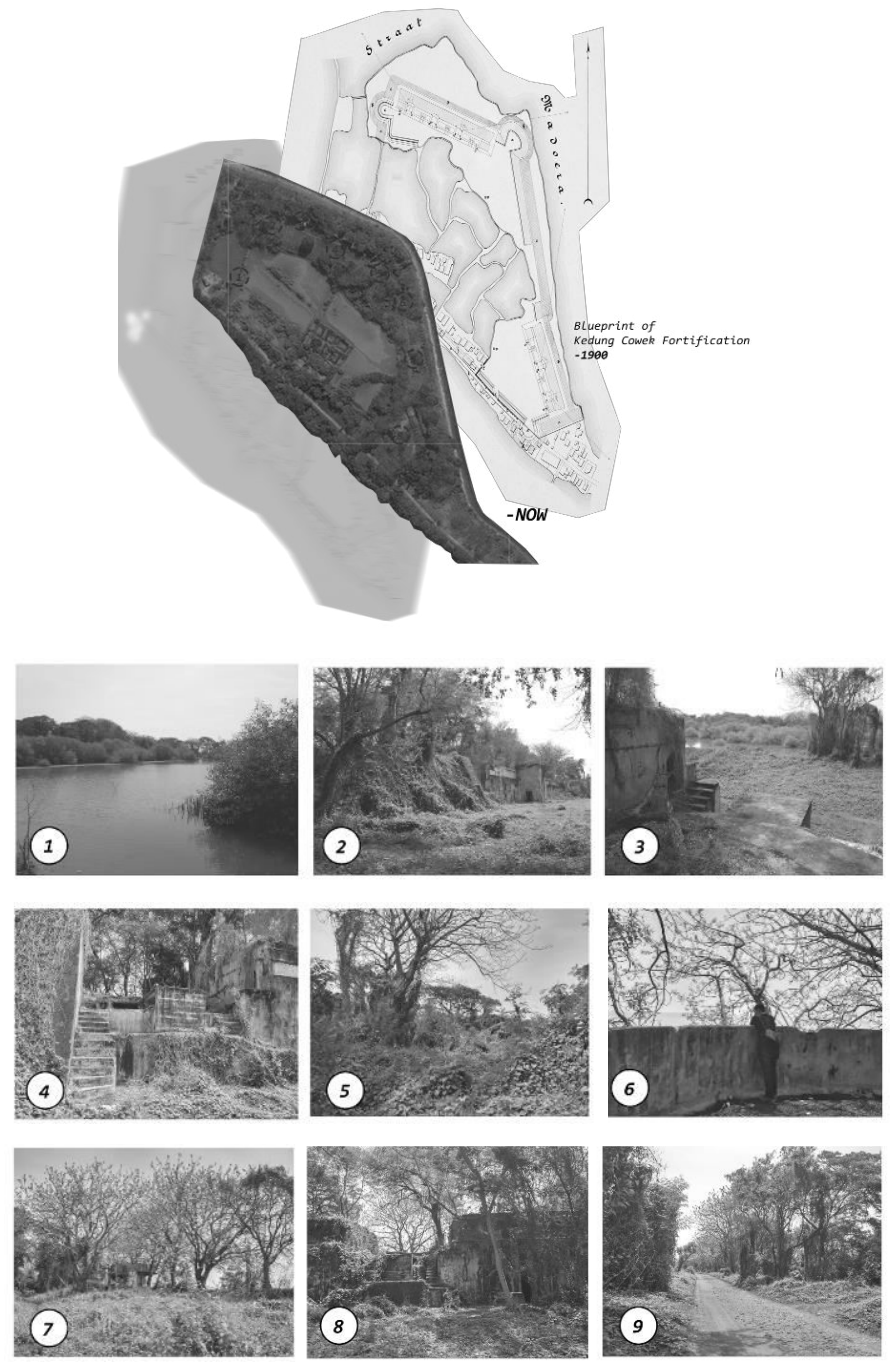

Figure 1. Kedung Cowek Fort and the Surroundings

Architecture has the power set the stage for occupants to create new meaningful experiences - and memory plays a key role in helping to make all of this possible. According to Elizabeth Grosz, memory is the present's mode of access to the past. The past is preserved in time, while the memory image, one of the past's images or elements, can be selected according to present interests [1]. Therefore, the abandoned fort could be revived, not as the product of the past, but as an 
instrument to deliver memory of history that could be understood by people of the present through the language of experience.

\section{DESIGN METHOD}

The approach used in the design is historicism and meaning in architecture. Historicism is a mode of thinking in which the basic significance of specific social context-e.g., time, place, local conditions-is central. The history of architecture is the identity of a nation because there are value of life rooting to the nation's character [4].

Kedung Cowek Fort, which has been built since 1900, is an important historical witness of Surabaya, and even Indonesia. Many wars that later played a role in the historical journey of Indonesia to finally achieve independence from colonialism. It was where Sriwijaya troops had to deal with Britain troops in October 1945, which was also bring Surabaya to the famous event of 'Sepuluh Nopember' war [2].

From the event happen in the past, the design proposal wants to bring back the value of the history and remind people about the spirit Indonesian people had in the past to achieve independence from colonialism through fighting in many wars. People also could see history from a different perspective, that it is important to keep maintaining the heritage. Those could be received by using meaning approach.

Meaning in architecture can be defined as the experience you provide to the users of the spaces you have designed. It is the impact you have on people's memory, people feelings received when they enter a place.

Those memories of history and values received by the meaning approach then delivered to visitors by using narrative method. Narrative is all constructed. It has real value. The capacity for provocation is precisely where its creative potential lies. The process of narrative can be laid out as a sequence, the author develops a story, the story then told to audiences [5]. While storytelling is about the construction of a story by setting up a timeline of events, design is based on the construction of a physical narration by organizing spatial relationships [6]. The architect is author of story in the design. The value architect want to deliver in design could be interpreted through many ways. The strength of intimacy is so absorbing that the reader doesn't read the writer's room anymore; he visualizes his own. (Bachelard, 1982: 41) "The success of the story for that reason lies in its ability to be interpreted and understood, so that it might take on a personal meaning for the reader" [6].

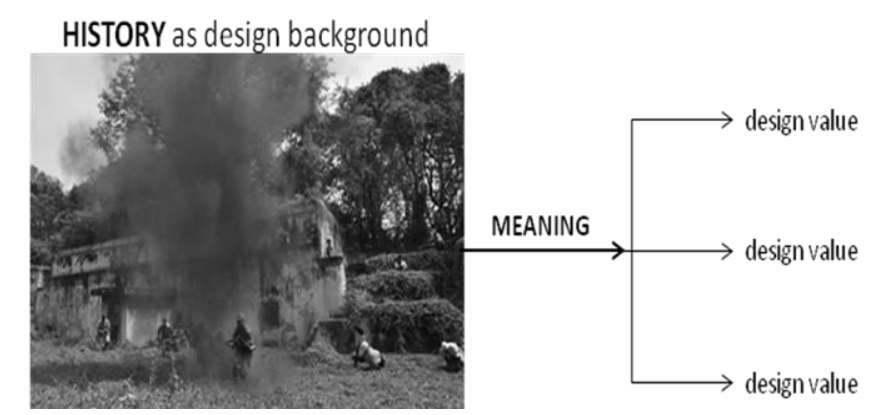

Figure 2. Role of Approaches in the Design.

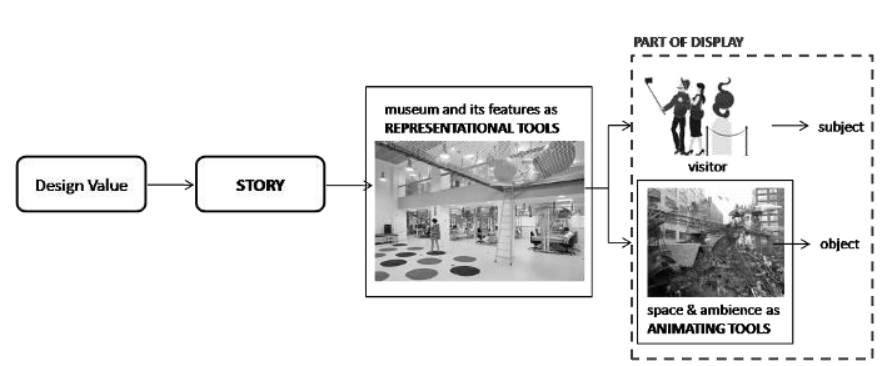

Figure 3. Role of Methods in the Design.

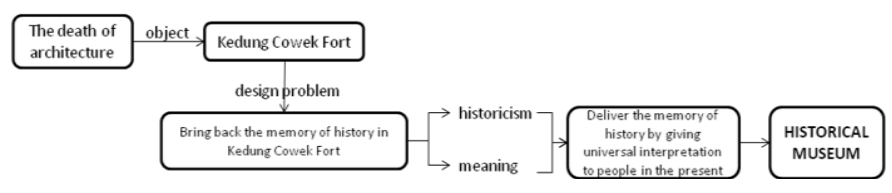

Figure 4. Thinking Process Summary.

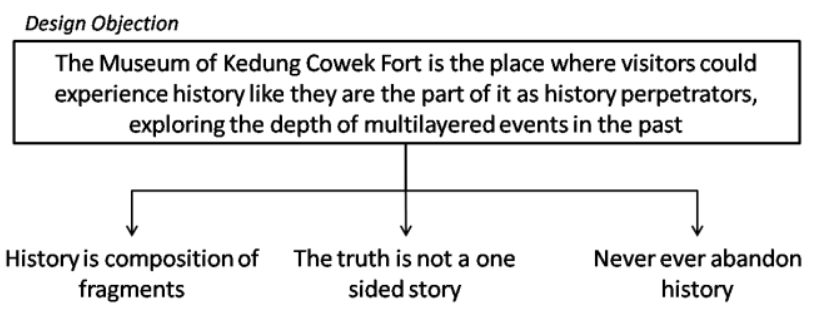

Figure 5. Design Objection and Values to be Delivered

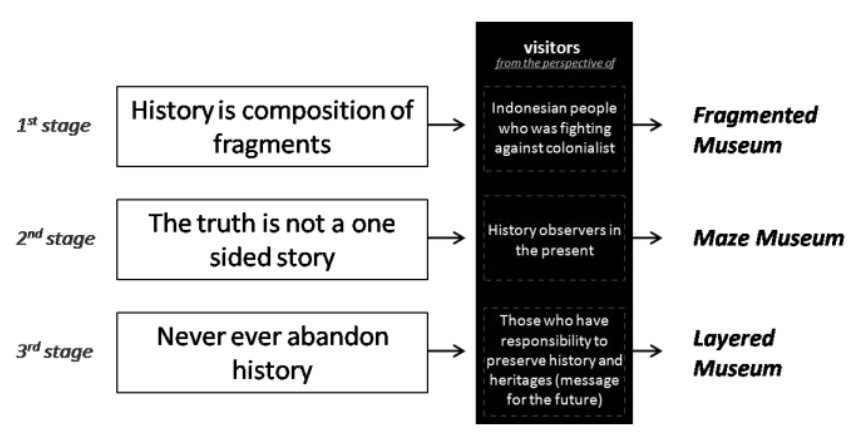

Figure 6. Three Stages of The Design Story.

\section{RESULT AND DESIGN EXPLORATION}

\section{A. Design Objection}

The building type proposed in this final project is historical museum. This museum is targeting on youth generation. So to make the history easy to be understood, the museum should be presented in the language of experience through architectural space, not as a conventional museum that just displaying things. It is not the timeline of history which will be presented in the design. The visitors should also know the lesson of life which could be gotten from events that have occurred in the past. By using meaning approach, the design proposal could achieve the goals to tell the value architect want to tell to people. There are 3 main values that architect want to give in the design: history is composition of fragments, the truth is not a one sided story, and never ever abandon history.

History is composition of fragments. It is unite but actually is formed by fragmented events in the past. No one in 
the present never really know in which order history actually happen in the past. Everyone has their own perspective about history. That is why history is not a one sided story and this concept then called as fragmented continuum concept. Even there are many events, many perspectives, they are all connected.

By using narrative method, the story is divided into 3 main stages which are represented by the museum and its architectural features. Architect is responsible to create the right animating tools through the facility and ambience in the design which will be used by visitors as the subject of story. With those in mind, space of the past would be brought back to 'life' because there are the visitor as subject and the design itself as the object which would create stories inside.

\section{B. Building Form and Color}

The design will be built in a historical context with the objection to convey stories of the past. Therefore, it should be harmonized with surrounding environment and let some existing parts look as they are from the beginning. If there is something really contrast in the design, it should be an accent to present narrative/story through meaning.

\section{Site Transformation and Scenario}

Fragmented continuum as a form could means many different pieces connected into an integrate composition. Therefore, the site plan is determined by using the concept of fragmented continuum as a guide.

In the site, there are 2 main existing forts and 1 small existing building. The idea is to connect those 2 existing forts. Then, arrange the connecting line so it has 2 main view orientation, first is to the swamp, and the second is to the sea. The connecting line as the building base also should avoid damaging more existing trees. After that, cut building base by the shortest way as a straight line so it is easy to go through. Lastly, give a way to access the small existing building in between.

After the arrangement of masses have been decided, sequences are made based on the building programs before.
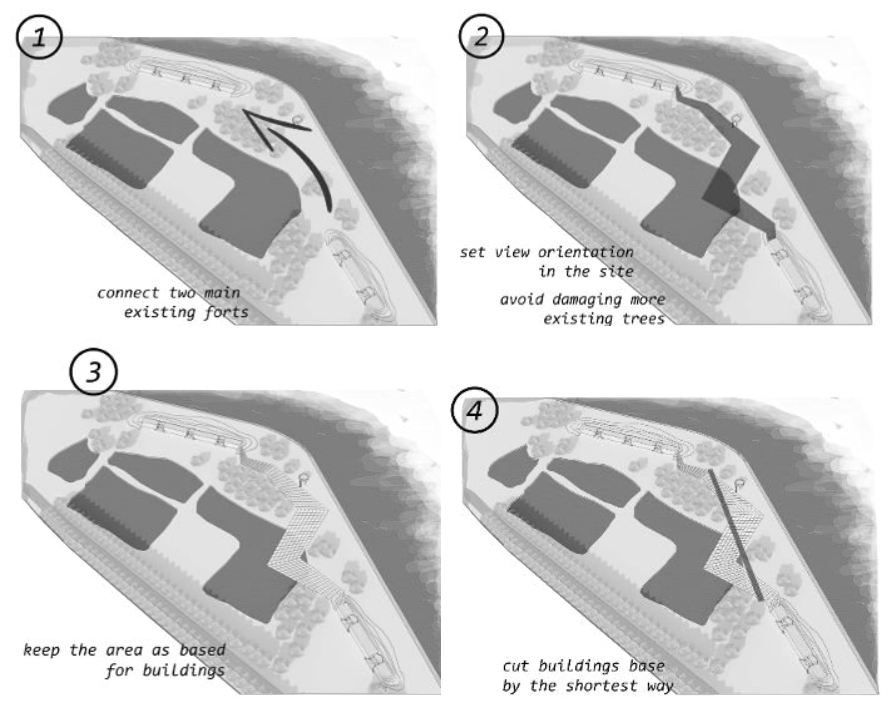
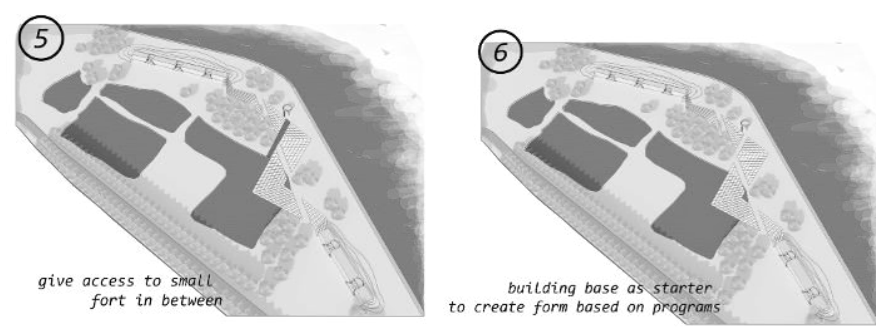

Figure 7. Site Transformation

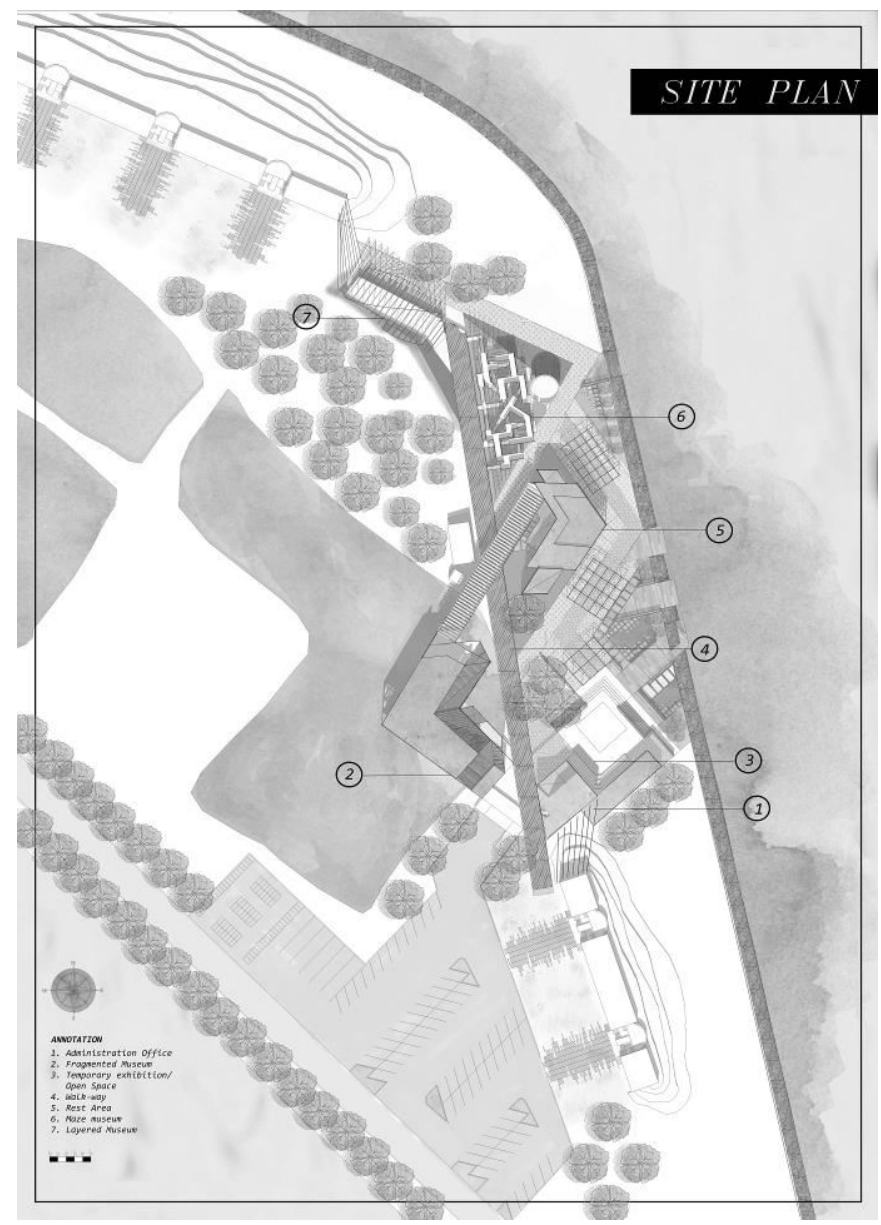

Figure 8. Site Plan.

\section{Fragmented Museum}

History is an arrangement of fragments. It is multilayered. The war is not the only issue to be considered as important events affect history. Behind it, there are also backgrounds of event, why actually it was happening, what people felt in the beginning, in the middle of war and after, how the war affected their life, how they dealt with it.

The first sequence represents humanity (2). It tells people that those who fought in wars also had their own life, their own family. They did not go to war because they really wanted to or they hate people. Soldiers and fighters are human, just like us. They could felt love and comfort. Those are represented by home ambience and pictures of soldiers good old memories.

The next sequence represents darkness of wars (3). It represents the dark time people had in the beginning of war. 
The third sequence is about damages and destruction as physical effects of war (4). In this sequence, people could see blurry images of the house where they lived before (in first sequence), had been ruined. It was caused by colonialists attack.

Then, people will going down to the next sequence where they could clearly see the ruins. This sequence tells how people in the past felt panic and fear (5). It is represented by how people should be fast in this room because if not, they will get wet from the water fountain that will be splashing one after another. There is also dark blurry image of people's feet on the ceiling (from the previous sequence. It represented as the pressure people had in that moment.

In the time of war, many people also lost their family and friends. The fifth sequence tells about that disappearance and loneliness (6). Visitors will be divided to two groups and they have to be separated to 2 different ways. One group should go down first. Then, another group could continue going forward. The first group will see layers of fabric covering the room as screen for a war video. They will going through all those fabrics to clearly see the whole room. The second group goes to a room which is tribute to heroes (7). The name of those who died in wars in the past will be attached on bamboo sticks hanging from the ceiling. Visitors will going through those sticks and hear those crashing one to another. This visualization represents an old quote. "Such silence has an actual sound, the sound of disappearance." -Suzanne Finnamore

Lastly, those two groups will meet in the end. They could continue going to the next building (8).

The building is using steel structure, which is tend to be lighter than concrete. It is because the proposed object should not causing damage to the land and existing building. Steel structure is also more effective in dimension. So, not much space will be used for supporting the structure.

Furthermore, the steel structure will be elevated. By using elevated steel structure, building footprint on the site could be reduced.

\section{E. Maze Museum}

History is not a one sided story. People live in time. The space has been replaced. Time is a space where people could create memory. Then, the memory creates history. People could not be fully-objective. Otherwise, history is subjective.

(1)
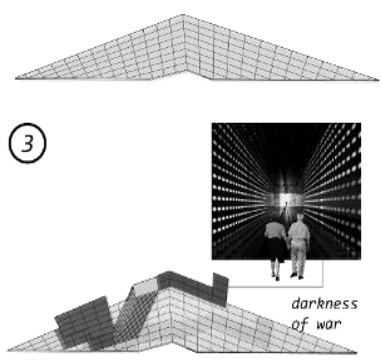

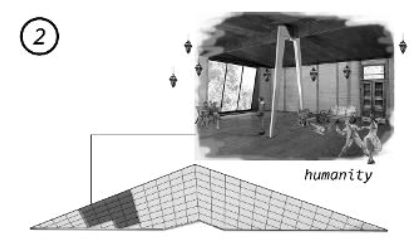

(4)

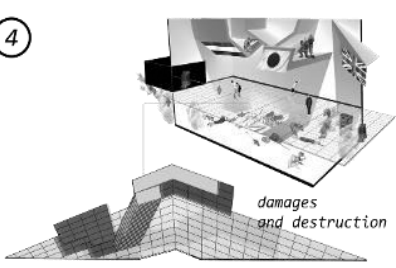

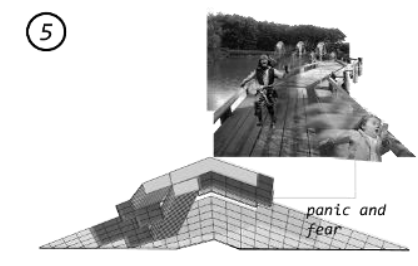
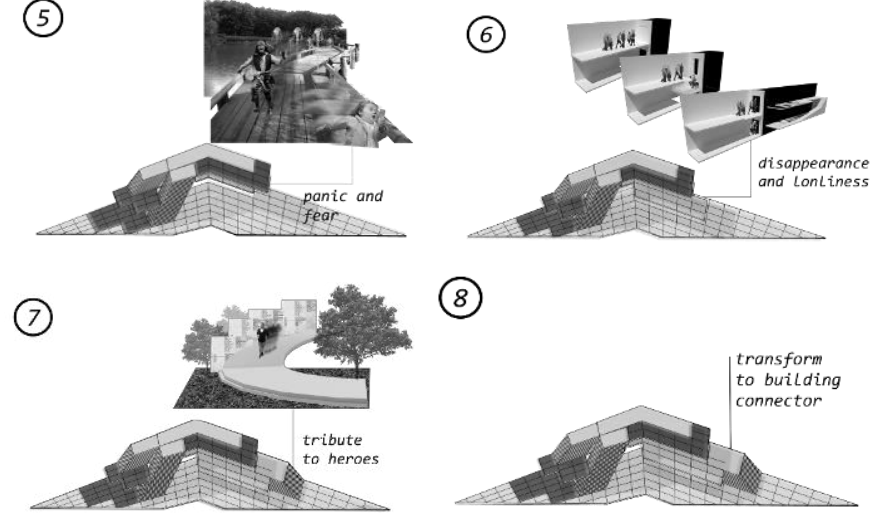

(8)

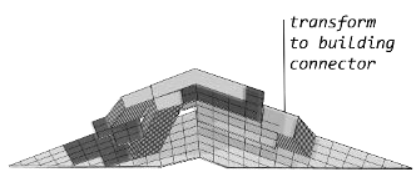

Figure 9. Scenario of Fragmented Museum
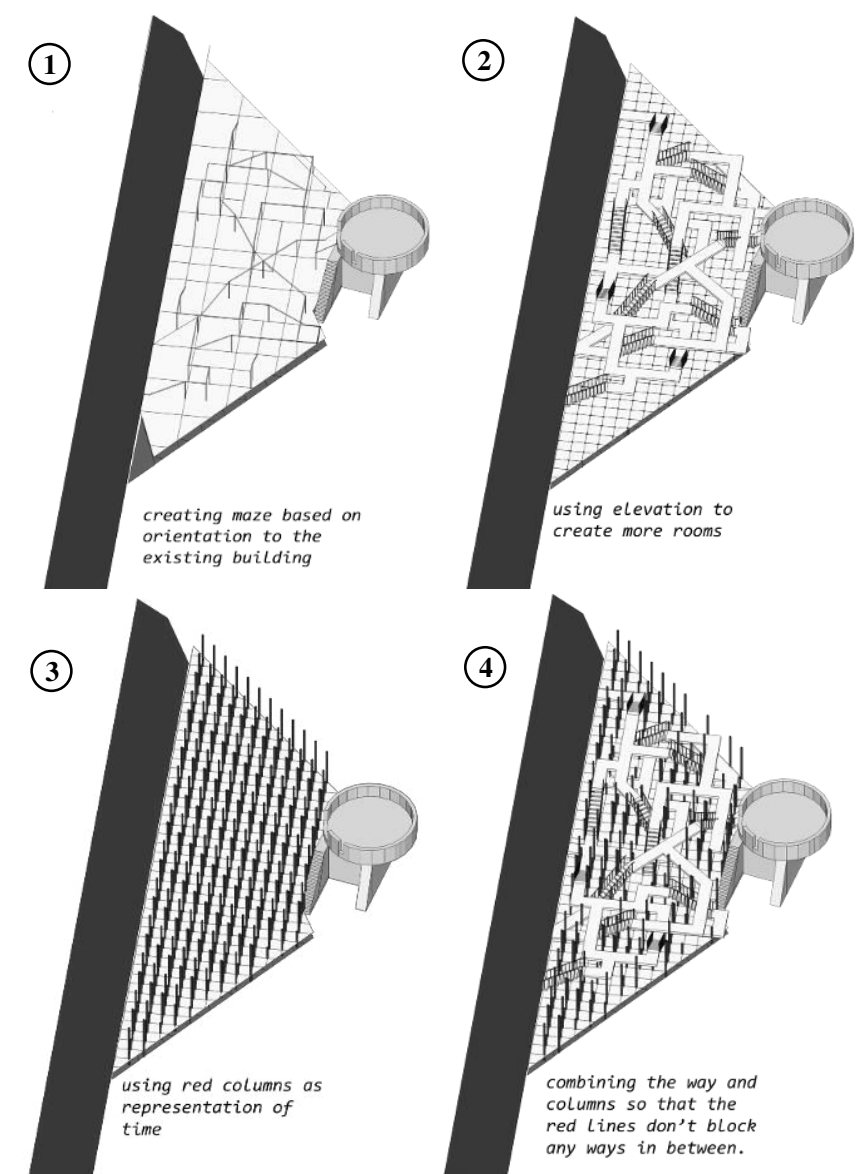

Figure 10. Scenario and Transformation of Maze Museum.

In the present, many people discover clues of fact in the past which are different with those written in history. No one know which one is the fact. But, those are still considered as history. This statement represents as a maze consist of two floors. This maze makes use of a small existing construction as a destination point. In the maze, people could read different timeline of history attached on the walls which are hanging below the second floor. Therefore, those walls position are in the point where the 2 nd floor superimposed with the first floor.

The experiences and timeline of history the visitor's see will be different one to another. Furthermore, those who could manage to choose the "right way" will get reward by going to the top of small existing building. 


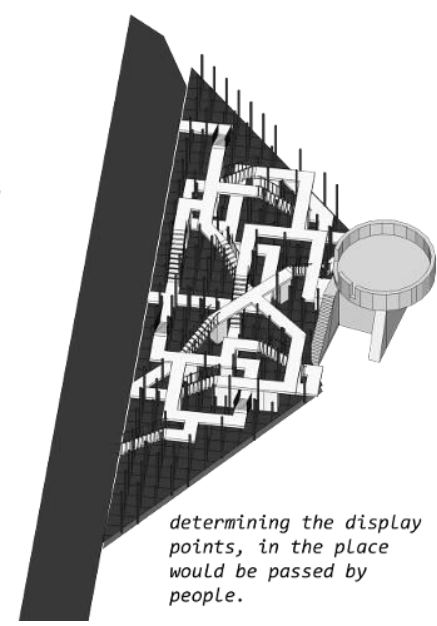

Figure 11. Maze Museum's Result of Transformation.

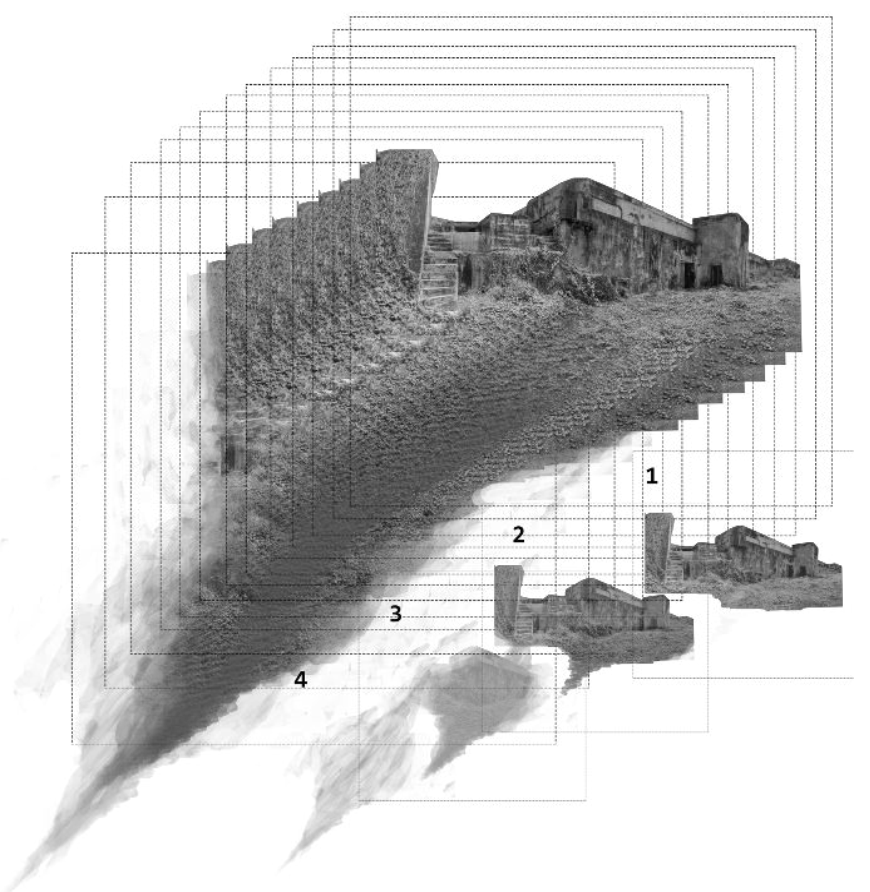

Figure 12. Concept of Layered Museum.

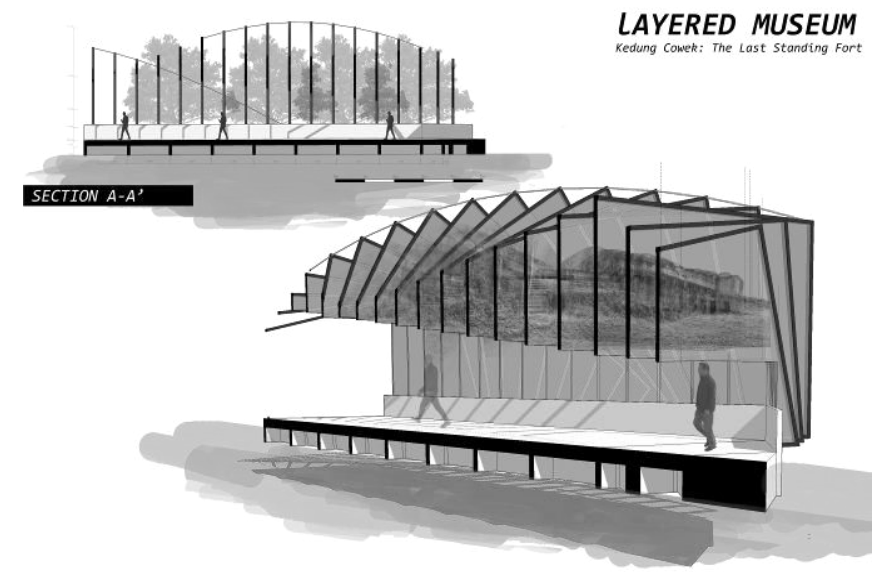

Figure 13. Section of Layered Museum.
Spesificly for maze museum, it needs structure to support the second floor by using minimal dimension of column. So, those columns will not blocking the track on the first floor.

\section{F. Layered Museum}

Never ever abandon history. Kedung Cowek Fort is called as the last standing fort. It is because compared to another forts which was built around Surabaya, Kedung Cowek Fort still has its entire construction and the structure tends to look solid. But, if it is left neglected, destruction could be possible one day. The government and also residents should maintain this fortress. Moreover, it is a heritage that once a witness of important history.

This message is represented by an alley leading to the biggest existing fort in the site. The alley is composed of transparent layers with picture of the fort on those layers. If visitors going further into it, they will see the pictures become darker and blurry until it vanishes on the last layer. In the end, they will see the real fort itself in front of their eyes.

\section{CONCLUSION}

Space of the past could be revived, not just by presenting timeline and witness of history. The architect should reinterpret the way people could experience the memory of history as a clear statement. In this case, the main statement of the design (Museum of Kedung Cowek Fortification) is fragmented continuum.

People in the present who do not experience the past events, could not easily understand the memory of history. Events in the past, will remain in the past. By giving the interpretation of historical background, people could try to understand the history from the perspective and story architect creates.

Furthermore, a good design gives impact to the present and future. In this case, Kedung Cowek Fort as a heritage building should be maintained well. Through this proposed design, the architect not just delivers the story, but also tries to convey the message for people to keep preserving history.

\section{WORDS OF GRATITUDE}

Thanks to Mr. Ady Setyawan, the author of 'BentengBenteng Surabaya', who always willing to give his time discussing about fort in Indonesia, especially Kedung Cowek Fort. And also to those who did not hesitate to help in the making of this journal.

\section{REFERENCES}

[1] T. Porter, Archispeak. London: Spon Press.

[2] A. Setyawan, Benteng-Benteng Surabaya. Yogyakarta: Mojok Store, 2015.

[3] N. Purwono, Benteng Benteng Soerabaia. Surabaya: Inti Grafika, 2011.

[4] Antariksa, Teori \& Metode Pelestarian Arsitektur \& Lingkungan Binaan. Yogyakarta: Cahaya Atma Pustaka, 2017.

[5] S. Macleod and et al, Museum Making: Narratives, Architectures, Exhibitions. New York: Routledge, 2012.

[6] C. Ampatzidou and A. Molenda, "Building Stories -- The Architectural Design Process as Narrative," in Proceedings of Digital Storytelling in Times of Crisis, 2014. 